\title{
XC. On an insect which is occasionally very injurious to fruit-trees
}

\section{William Spence Esq. F.L.S.}

To cite this article: William Spence Esq. F.L.S. (1822) XC. On an insect which is occasionally very injurious to fruit-trees, Philosophical Magazine Series 1, 59:290, 439-445, DOI:

10.1080/14786442208652771

To link to this article: http://dx.doi.org/10.1080/14786442208652771

里 Published online: 29 Jul 2009.

Submit your article to this journal $\sqsubset \pi$

Џ Article views: 2

Q View related articles $\sqsubset$ 
thrown over the bushes, lime, and chimney-soot, and a strong decoction of elder leaves; but who can eat gooseberries and currants after they have been besmeared with such fithy materials, which at best apply to the evil in part? But, if any one can discover a means of keeping off the fly by the smell of something which is disagreeable to it, it goes to the root of the evil at once; and there is nothing in the smell of coal-tar which can excite a prejudice in the most delicate stomach. If this should not generally succeed, what has been said upon the subject may perhaps be the means of some of your chemical and philosophical correspondents finding out something that will. Black pepper keeps off the flies from meat, and it is by no means impossible that a discovery may be made to keep these flies from the gooseberry-bushes: for I am well assured, that there can be no effectual remedy for this evil, but the discovery of something the effluvia of which will produce this effect : and the season is now approached when the attempt should not be neglected: for, if the first invasion succeeds in making a lodgement, it may not be so easy to prevent a second and a third from taking entire possession of all the bushes. It is upon this principle of creating an offensive smell, that turnip-seed is recommended to be steeped in train-oil before it is sown; and it is said to be a perfect security against the bite of the turnip-fly.

Totness.

J. C.

XC. On an Insect which is occasionally very injurious to FruitTrees. By William Spence, Esq. F.L.S.*

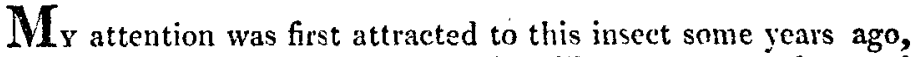
by observing small masses of saw-dust-like excrement, the usual indication of the presence of larvæ, protruding from the edges of the cankered parts of a very diseased summer apple-tree, of the name of which $I$ am ignorant. On cutting off a portion of the wood, I found many small white larvæ inhabiting cavities which they had excarated between the bark and alburnum, and sometimes wholly in the latter, upon which they seemed to feed. These larvæ were of different sizes, and amongst them were several chrysales, which having detached, and placed under a glass, they produced in a few days the Tortrix Woelerana, a small moth very. abundant in the garden, and thus proved to be the purest of the larvæ.

I at first supposed that these insects, like many others, deposited their eggs only upon parts of the trees previously diseased. Even on this supposition, their injurious effects would be

* From the Transactions of the London Horticultural Society. 
very considerable, as it was rlear that they every year greatly enlarged the extent of the canker, not merely by devouring the neighbouring alburnum, but by forning numerous cells in it, which when quitted by the chrysales are filled with water by every shower, and thus become the source of more speedy and extensive decay. Many of the cankers in the tree above alluded to, have eaten half-way through the small trunk and branches, which if not sheltered by a wall must have been long ago broken off by the wind.

This tree is a remarkable example of the effect of partial decortication, as recommended by Dr. Darwin (Phytologia, p.378), in inducing the production of flower instead of leaf-buds. Not only the bark, but half the trunk, as above observed, is eaten through in many places; yet though a new twig is scarcely ever put forth, it never fails to be laden with blossom and fruit. Here I may observe that a similar result, as to the increased produce of fruit, and the paler green of the leaves, with that above referred to by Dr. Darwin, I have myself seen on a branch of a pear-tree, from which nearly a complete cylinder of bark had been gnawed by cattle. It was filled with fruit, while not a pear was to be seen on the rest of the tree.

Narrower examination, however, has shown me, that their attacks are by no means confined to the diseased parts of fruittrees; nor directed, as I at first conjectured, against the appletree only. Being more anxious to ascertain the oeconomy of an injurious insect, than desirous of preserving the tree which they chiefly attacked, I took no steps for extirpating them; and they have, in consequence, seemed to increase every year since I first observed them, and last year carried on their operations so extensively, as to threaten more serious injury in return for my forbearance, than I had calculated upon. Not only were they more than usually abundant near the margins of all the old cankers, but J observed their masses of excrement adhering, in every direction, to the surface of the healthiest pear-and apple-trees in the garden; and wherever these indications appeased, the application of the knife aways detected the caterpillar beneath.

It is thus evident that, where they abound, no other cause is wanting to generate canker and disease. Though their attacks upon the bark ond alburnum should not at first be extensively injurious, the admission of water into their empty cells, and frequent reperitions of the mischief, must, in the end, cause rottenness; and it is perhaps not improbable that to these insects should be often primarily attributed the canker laid to the charge of the soil, or the mode of cultivation.

After these prefatory remarks, I shall proceed to describe the insect in its different states, adding such observations as have 
occurred to me upon its ceconomy, and the most probable means of extirpating it.

Eggs.-I have never been able to detect any of these upon the parts of the tree where I conjecture they are laid; but several were depusited on the sides of a glass jar, under which I had kept the two sexes from their first exclusion. They are lentiform, flat below, slightly convex above, smooth, pale red in the middle, with a white and apparently membranous margin. Altogether they very nuch resemble the seeds of the common garden stock, except that they are not above one-fourth of the size; and they presented an appearance so very dissimilar to that of the eggs of insects in general, that 1 for some time overlooked them.

Larva.- The eggs abo"e mentioned not having produced any larvæ, I ain unable to say any thing as to the precise period at which they are hatched; but from observations made on those found in the fruit-trees, I conjecture that they appear very shortly after the eggs are laid, and immediately proceed to insinuate themselves beneath the bark. When full grown, they are from four lines to balf an inch long, and abont a line broad; and wholly of a dull semi-transparent white colour, except the head, which is pale chesnut, which with the adjoining segment is also sometimes tinged. In some specimens, an obscure reddish line runs along the body, which is owing to the red colour of the fuid contained in it. 'The body, besides the head, consists of twelve segments, which, owing to the wrinkles in the three first, are not very easily counted. To each of the three first segments lelow, are affixed the usual pair of clawed feet, the claws of which are sometimes yellowish; and a pair of tubercular or false feet, as they are often called, are attached to the $6 \mathrm{th}, 7 \mathrm{th}, 8 \mathrm{th}, 9 \mathrm{th}$, and 13 th (or last) segments: so that in all the insect has, as is usual in this tribe, sixteen feet; six clawed, and ten tubercular. Each of the scgments above, is furnished with from four to six slightly elevated protuberauces or mamillix, more polished than the rest of the body, of a rather darker colour, and having one and sometimes two short stiff white hairs proceeding from each. As these mamilie seem to furnish the best characters for discriminating these larve from others of the same tribe closely allied to them, it will be necessary to advert to their number and position more narrowly.

There are none on the first segment. On the second, third, and last, are four placed in a transverse line: and on each of the remaining segments, that is, from the fourth to the eleventh inclusive, are six, one on each side and four in the middle, forning a square, of which the two anterior are larger and nearer to each otlier than the two posterior. It is to be oberyed that Vol. o9. No. 200. June 152\%. 
this description applies only to the lack of the larva, as both the belly and sides have other similar mamillx, which it is unneces. sary to particularize. The period in which these insects exist in the larva state, is, as far as my observations extend, about a year; during the whole of which, except in winter, when they probably lie torpid, they are employed in boring into the bark and alburnum. As the female moth seems to deposit her eggs through the whole summer, the larvæ may be always met with, and of very different sizes.

Chrysalis.-The larvæ which are then full grown, and these are the greater number, assume the state of chrysalis about the latter end of May, soon after which time many of the empty husks from which the moths have escaped, may be seen projecting from the bark: and from this periorl, to the end of summer, others, lying still undisclosed within their silk-lined cavities, are found on cutting into the wood. The chrysalis has the usual sub-conical shape of those of the tribe of Tortrices. It is about one-third of an inch long, and a line broad in the widest part; of a pale yellow colour when first disengaged from the larva, but nearly brown when mature; and smooth, except that each abdominal segment is set with two transverse lines of aculei, or little teeth, pointing towards the tail, of which those in the line nearest the head are larger and fewer in number than those in the line next the tail. These aculei, which are found in the chrysalis of most species of Tortrix, evidently serve for enabling the insect, when in this state, to move itself to the entrance of the orifice in the bark, previously to escaping in its perfect form. 'The tail, when viewed under a lens, is found to be furnished with seven or eight minute hooks.

Perfect Insect.-After remaining in the chrysalis state about ten days, the moth breaks forth. Of this the following is a description :

\section{Tortrix Webrrana.}

T.-Upper wings chocolate-brown, variegated with orange and silver streaks.

Pyralis Woeberana. Falricius Mant. Ins. II. p. 230. $u^{0} 52$. -Ent. Syst. III. ii. p. 259. $n^{\circ} 71$.

Tortrix Woeberana. Wiener Verzeichniss, 4to edil. 126. 9.; Svo edit. II. 43. Fam. B. $n^{\prime \prime}$ 9.-Haworth Lepidopt. Brit.p. $457, n^{\circ} 201$.

Phalæna Tortrix Woeberana. Gmelin Syst. Nat. I. p. 2511.Turton's Translation, III. p. 350.-Brahm Insekten Kalender II. p. 252. $n^{\circ}$ 145. -De Villers Ent. Linn. IV. t. 525 .

Tortrix ...... Hiiliner sichmet, Tort, 32, 6. 
Description.-Head brown, margined behind with orange. Probuscis short, pale yellow, spirally convoluted between the palpi, which are large, subtriangular, yellow, the apex and minute terminal joint black. Antenne one-third the length of the body, setaceous, not pectinate, brown, the first joint, which is thicker than the rest, vellow. Thorax brown, with two interrupted irregular transverse bars of orange. Upper-wings brown, beautifully variegated with many irregular streaks of orange, and a few of silvor. The silver streals are sitnate chiefly nest the margin : one just above the midlle of the wing, anteriorly dividing into a fork, whose ends approach the margin; another below the middle, extending in a curved direction nearly to the apes, and sending off anteriorly two or three branches towards the inargin. These silver lines are margined with orange, as are two other short transverse silver lines near the inner angle of the apex of the wing, which include a small silver spot, and two longitudinal orange bars. Besides numerous orange streaks and marks, which it is unnecessary to describe minutely, the wings are characterized at the outer margins by about six short oblique yellow spors. At the apes they are fringed with brown cilia, which in some lights have a metallic shade, and are interrupted by two longitudinal bars of yellow cilia. Under-wings, above wholly of a brownish black, except at the outer margin from the base to the middle, where they are white. At the apex they are fringed with cilia, white at the apex, and circumscrihed just above the brown base with a very fine and almost imperceptible white line. Under-side of the lody and legs of a silvery or pearly white; the tibice and tarsi of the latter ringed with black. Length of the body about one-third of an inch ; of the wings, when expanded, from half to three-guarters of an inch.

Long as the above description may seem, it will not be deemed too minute by any one acquainted with the difficulty of discriminating many of the minuter species of this tribe of insects; nor could I have contracted it consistently with the object I have in view, that of enabling any gardener to recognise the moth in question.

How long these moths live after being excluded from the chrysalis, I am not able to say; but from aralogy, and the circumstance that some which I reared under a glass jar did not survive above a week, I conclude their term of existence does not much exceed that period. Hence, as I find them in my garden from May to the middle of August, it is clear that they are not, lihe many other insects, confined to one term of exclusion, but are issung from the chrysalis throughout the whole summer: in greater number, however, in June than afterwards. In the day-time they usually remain sitting at rest on the trunks 
and branches of the trees from which they have emerged; fiying about, like other moths, only in the night. The sexes, judging from those I reared under glass, copulate soon after their exclusion from the chrysalis; and as the female, as remarked by Brahm, is not provided with any instrument for piereing the bark, it is probable that she deposits her eggs on the outside of it, the young larva subsequently making their way into the tree.

The only work in which I have found any allusion to the conomv of this insect, is a German publication, Brahm's Insekten Kalunder. In this it is briefly observed, that the larve winter in the trunks of apricot-and almond-trees, upon the sap of which they are supposed to live, and to which it is conjectured they are cory injurious.

With regard to the vest mode of destroying these insects, when their attacks are injurious, I have nothing better to offer than a few inuperfect hints. Tlıe first and most essential process evidently is, to cut away the edges of the cankers where they are chiefly found, making the wound smooth, and covering it with any composition likely to prevent the moth from depositing lier eggs there again. One precaution is necessary, to put into boiling water, or bury at a consilerable depth, the cut out pieces of decayed batk containing the larve; which, if left near the tree, would soon crawl from their holes and remount it; thus defeating the labour of the horticulturist, who, often, from neglecting a slight additional trouble, loses she benefit of more painful excrtions.

Rösell tells us (Irsektcn Belusticung, 1. iv. 171.) that the German gardencrs, after collecting from their cabbages, with unwearied industry, whole baskets full of the destructive Noctua Brasice, bury them in a shallow hole in the earth; thus unwittingly counteracting their object in the most effectual way. For as this insect naturally undergoes its metamorphosis under ground, and many of the larve are full grown, they assume the chrysalis form in the hole into which they have been thrown, and in a few weeks emerge in the moth state, ready to lay thousands of eggs for a new brond.

Where the larve are found to have insinuated themselves generally into the rough bark of old trees, it would probably be advisable to adopt Mr. Knight's judicious recommendation on an. other occasion, and scrape off the whole of the lifeless bark, and such portions of the alburmun as are injured; a process which, there can be no doubt, would be advantageous to the tree in other respects pointed out by Mr. Knight. Where projecting saw-dust-like masses show that the larva has attaclied even smooth-barked trees, the insertion of a blunt pricker into the hole would probably, in mont cases, suffice to destroy it, and do 
less injury to the tree than suffering it to attain its growth. But the mode which I should recommend in this, as in the case of almost all insects injurious to the horticulturist, is to employ children in the summer months to destroy the moths themselves, giving a small premium for every ten or twenty they collect; and increasing it as the numbers beconse lessened. When taught where to look for them, they would discover numbers on the bark of the trees; and, if provided with gauze clasp-nets, would find it a most healthy and interesting occupation to catch them when made to fly by shaking the trees and bushes in which they repose. The destruction of every female moth, before the deposition of its eggs, may be fairly calculated to prevent the existence of some hundreds of larva; and thus in any garden not in the neighbourhood of others where the same methods are neglected, the whole race might in a few years be extirpated.

XCI. On a new Method of determining the Latitude of a Place by Olservations of the Pole-Star. By Francis Banix, Esq. F.R.S.*

I

$T$ is well known that the usual mode of determining the latitude of a place is by observing the zenith distance, or the altitude, of the sun or certain of the fixed stars at the precise moment of their passing the meridian. But, although this point of time might appear the most favourable for such observations, yet, by the assistance of a refined analysis, the modern astronomer has been enabled to extend the period of such observations to several minutes on each side of the meridian; and the results are, by the help of certain tables constructed for that purpose, rendered as correct as those which are taken immediately at the time of culmination.

Of all the stars which have been observed for this purpose, none have engrossed so much the attention of astronomers, as the pole-star: and, in fact, it is almost the only one which is now resorted to on such occasions. Its proximity to the pole renders it highly favourable for such observations in this hemisphere; it being on that account, and from its magnitude, visible (with telescopes of no very considerable power) at all tines of the year, by day as well as by night.

But there is another important advantage to be derived from its small polar distance, which, till of late years, appears to have escaped the attention of astronomers; and which it is my object, in the present communication, to point out to those who may not have considered the subject: viz. that the latitude of a

* Communicated by the Author. 